\title{
CONCEPTIONS AND IMPLICATIONS OF A 'CIVILISING MISSION': ROMAN VIEWS OF GERMANS, GAULS AND BRITONS COMPARED WITH THE PERCEPTION OF THE XHOSA BY SIR HARRY SMITH
}

\author{
A van Wezel (Rhodes University)
}

\begin{abstract}
Roman descriptions of remote and strange north-western peoples were fraught with images of wildness and an idea of the 'barbaric'. Barbari was a term loaded with negative connotations, the antithesis of the concept of Roman humanitas. Descriptions of the 'other' by British colonials in the $19^{\text {th }}$ Century Cape, such as Sir Harry Smith, differ little. Smith describes the Xhosa as a savage and barbaric people, in comparison to the seemingly superior 'civilization' of the British. In both situations, these stereotypical negative portrayals of an inferior or even inhuman people, served to justify a policy of conquest, domination and very often maltreatment. The question of whether or not barbarism was innate or learnt has implications for the idea of the 'other' as 'convertible' to the culture of the 'civiliser'. Both Cicero and Smith write of barbarism as a state of society that has the potential to change, reflecting on their own societies' progression to a supposed state of 'civilisation'. The assumption that their own 'civilised society' had been the outcome of adopted behaviours provided much potential justification for cultural intervention in the society of the 'other'.
\end{abstract}

Keywords: Sir Harry Smith; othering; Xhosa; Britons; Gauls; Germans; Roman; Cape Colony

'Savages we call them because their manners differ from ours, which we think the perfection of civility' - Benjamin Franklin ${ }^{1}$

\section{Introduction}

By 1834, when Sir Harry Smith charged on horseback from Cape Town to the frontier of the Cape Colony ${ }^{2}$ to fight the Xhosa people in what would become known as the Sixth Frontier War, he had already been serving in the British army for almost thirty years, seeing military action in South America, Spain and the American colonies. ${ }^{3}$ During Smith's involvement in the administration of the

\footnotetext{
1 'Benjamin Franklin Quotes' at: www.nationallibertyalliance.org/files/docs/foundingdocs/Franklin\%20Quotes.pdf

2 Smith, H in Moore Smith 1901, vol. 2. pp. 12-16 (Hereafter referred to as 'Smith, Autobiography'.

3 Ibid., vol.1.pp. 1-300.
} 
eastern districts of the Cape Colony, he insisted on implementing a policy that had an immediate impact on the lives of the Xhosa people living under his authority after the Sixth and Seventh Frontier Wars (1834-1836 and again 1847-1852). This policy was based on his belief that it was his duty to 'civilise' (a controversial term discussed in more depth below) other groups of people who lived differently from the English. While Smith's beliefs would have been influenced by prevailing ideologies at the time, ${ }^{4}$ his particular views of the 'other' and methods of 'civilising' also appear strongly similar to Roman writings before AD $300^{5}$ on Germans, Gauls and Britons. ${ }^{6}$ This is not entirely surprising if one keeps in mind that being educated and well-read around the turn of the nineteenth century, Smith was familiar with Latin literature, ${ }^{7}$ a fact that is obvious from various quotations in his writings, ${ }^{8}$ which were surely quoted from memory.

4 Ideologies that became increasingly prominent in the 'West' during the nineteenth century were 'Christianising' and 'civilising'. They were spread and supported by the missionary (Jahoda 1999:143) and humanitarian movements (Strobel 2008:73-75, 80). Crais also writes of a colonial identity that emerged among the settler elite in the Eastern Cape that rested on the idea of themselves as 'civilised' and the 'other' as 'savage' (Crais 2001:95, 121, 125-146).

5 I chose to halt my research before the introduction of Christian doctrine into Roman government, as it would have added another dimension to the study of Roman conceptions and ideas, the scope of which cannot be justly dealt with in an article of this length, although the implications are worth further investigation.

6 My reasons for focusing on Roman views of north-west European peoples is that much scholarship has already focused on Orientalism and Greco-Roman views and ideas of the Eastern 'other' (Said 1978, Hirsch 1985, Lester 1998b:2, King 1999, Macfie 2002, Varisco 2007, Gruen 2010:1, Hirsch 1985). Woolf is one of the few scholars to recently focus on the portrayals of people of the 'Roman West' (Woolf 2011). I, like many before me (as pointed out by Woolf 2011:2), am fascinated by the analogy and hope to highlight the irony behind British views of the 'barbarous other', since they were once, as a people, viewed as exactly that by the Romans whom they culturally revered. $C f$. 'The idea that even Britain had to undergo "Romanization" before reaching its potential as a nation was critical for their use of the Roman model for their new empire in India'. Mantena 2011:58.

7 Nineteenth century British education was dominated by the classics (Stray 1998, Stray 2001, Woolf 2011:2). Harry Smith, in particular, mentions briefly in his autobiography that he was 'taught natural philosophy, classics, algebra and music' (Smith, Autobiography vol.1, p.1) and it is known that he had knowledge of classical literature and history, some of which he may have learned from his education under Rev George Burgess in a small schoolroom of St Mary's Church in Whittlesea (Moore Smith 1901:1.1, Harington 1980:4, Lehmannn 1977:2).

8 Some examples of his quotations include: 'prohibenda [autem], maxima [est] ira in puniendo' from Cic. Off. 1.89 (Smith, Letter to D'Urban 30 July 1835, in Smith, Col. HGW, Letterbook, Eastern frontier, 1835-1836 [GH 34/7-8] The Western Cape Archives and Records Services (This collection hereafter referred to as Letterbook)), 


\section{Defining 'civilisation'}

The concept of 'civilisation' is complex. As a foil to images of barbarism, the Romans used the word humanitas, which they identified with being Roman. ${ }^{9}$ Loosely translated as 'civilisation', ${ }^{10}$ this complicated concept embraces two ideas. ${ }^{11}$ On the one hand it means 'culture', inevitably a Greco-Roman culture, often associated with Roman wealth, commodities, fashion, ${ }^{12}$ land cultivation, agriculture, ${ }^{13}$ urbanisation, ${ }^{14}$ law, ${ }^{15}$ religion, ${ }^{16}$ education, literacy, and language. ${ }^{17}$

'[pax] vel iniusta utilior est quam iustissimum bellum' from Cic. Att. 7.14 .3 (Smith, Letter to D'Urban 23 Aug 1835, in Letterbook), 'cavendum est etiam, [ne] major poena quam culpa sit' from Cic. Off. 1.89 (Smith Letter to D'Urban, 19 December 1835, in Letterbook), 'fama [...] mobilitate viget viresque adquirit eundo', from Verg. Aen. 4.174-175. (Smith, Letter to D'Urban, 21 Feb 1836, in Letterbook), 'voluntas est quae quid cum ratione desiderat', from Cic. Tusc. 4.12 (Smith, Letter to D'Urban, 7 March 1836 in Letterbook), 'nihil [esse] in vita magno opere expectandum nisi [laudem atque honestatem]' from Cic. Arch. 14. (Smith, Letter to D'Urban 2 July 1836 in Letterbook). See also the comment in Harington 1980:4.

9 Cicero writes of a rustic way of life as the opposite of humanitas atque leges (Cic. Cael. 26). 'Law' (ius) and humanitas are opposed to a way of life that is barbarous (Cic. Sest. 92 cf. Rep. 2.27, 2.48). For a similar contrast see Cic. Leg. 2.36: ex agresti immanique vita exculti ad humanitatem (cf. De Or. 1.32-3). Cicero describes mankind as falling into two classes: one 'uneducated and rustic' (indoctum et agresti) and the other 'humane and cultivated' (humanum et politum). He uses the superlative form immanissimus of those who belong to the former class (Cic. Part. Or. 90). Vitruvius makes a similar contrast: e fera agrestique vita ad mansuetudinem ... humanitatem (Vitr. 2.1.6). cf. Vitr. 2.8.12: humanitatis dulcedine mollitis animis barbarorum. Valerius Maximus makes the same point in very similar words: humanitatis dulcedo etiam in efferata barbarorum ingenia penetrat (Val. Max. 5.1.6). See also Miller \& Savage 1977:118.

10 Veyne 1993:343.

11 Woolf relates humanitas to the Greek concepts of philanthropia and paideia, a general regard for human worth and culture as intellectual property of an educated and cultivated person (Woolf 1998:55 cf. Wilkinson 1982:231, Veyne 1993:342). He also defines humanitas as embracing other Roman concepts such as benevolentia, observantia, mansuetudo, facilitas, severitas, dignitas, and gravitas while connected with concepts such as religio, fides and mores (Woolf 1998:55).

12 Caes. $B G$ 1.1.3, $c f$. 4.3.3-4.

13 Cic. Flac. 62, Red. Quir. 4, Plin. Ep. 8.24.2.

14 Cic. Sest. 91, Red. Quir. 4, De Or. 1.33. The English word 'civilisation' has its roots in the Latin civis / civilis which refers to an urbanised community (Ayto 2002:393). Although the Romans made the connection between urbanisation and humanitas, Smith, in the rural frontier of the Cape Colony, connects civilisation more with cottage rural living than with urbanised towns (See footnote 91).

15 Cic. Cael. 26, Flac. 62, Sest. 91, Verr. 2.4.98, 2.5.187, De Or. 1.33, Part. Or. 90, Vitr. 9.pr.2.

16 Cic. Flac. 62. 
On the other hand it stands for a general regard for human worth, ${ }^{18}$ associated with ideas of manners, kindness, ${ }^{19}$ virtue, nobility, ${ }^{20}$ rational thought and intelligence. ${ }^{21}$ It is significant to note that the Romans, in the way they used this single word humanitas, equated their own culture and ways of life with good morality. Veyne argues that humanitas was both an internal modification of an individual person that by Cicero's time had become a popular attitude, a kind of politeness and manner ${ }^{22}$ and an indication of human ascendancy over the external world, through cities, and agriculture. ${ }^{23}$

Similar to the Roman idea of humanitas, Smith equated his idea of 'civilisation' with English commerce, clothing, ${ }^{24}$ agriculture, ${ }^{25}$ education and knowledge, ${ }^{26}$ as well as virtues of honesty and goodwill ${ }^{27}$ - which he viewed as an antithesis to the culture of the 'other': the latter he labelled barbarous, savage and cruel. ${ }^{28}$ The construct of 'civilisation' was used to place different cultures in a hierarchy, making one culture, their own, seem more 'right' than another. The added element of Christian religion to the idea of civilisation ${ }^{29}$ greatly enhanced its moral implications in the nineteenth century.

17 Cic. Cael. 54, Flac. 62, Lig. 12, Verr. 2.4.98, Div. 1.2, Leg. 2.36, De Or. 1.32, Plin. HN 5.45, Plin. Ep. 8.24.2.

18 Woolf 1998:55, Wilkinson 1982:231.

19 Cic. Cael. 25, Verr. 2.5.187, Leg. 2.36, Rep. 2.27, Vitr. 9. pr.2.

20 Cic. Lig. 12, Off. 1.62, Planc. 58, Part. Or. 90.

21 Cic. Planc. 58, Verr. 2.4.98, Sen. 1, Vitr. 9. pr.2.

22 Veyne 1993:352.

23 Ibid., 343.

${ }^{24}$ Smith, Autobiography p. 89, Smith, Address to Caffer Chiefs 7 Jan 1836 in Autobiography.

25 Smith, Autobiography p. 90.

26 Smith, Address to Caffer Chiefs 7 Jan 1836 in Autobiography, Smith, Autobiography p. 90, Smith, Letter to Grey 17 Mar 1849 in Correspondence (1853).

27 Smith, Address to Caffer Chiefs 7 Jan 1836 in Autobiography.

28 Smith, Letter to D'Urban 17 April 1836 in Letterbook, Smith, H, Letter to D'Urban 20 Oct 1836 [MS 482] Cory Library, Smith, Letters to Godlonton 10 Feb 1837, 22 Dec 1850, 16 Jan 1852 in Godlonton Corresp., Smith, H, Letter to Lord Glenelg 15 Dec 1837 [MS 501] Cory Library, Smith, H, Letter to Sir G. Napier 28 Jan 1838 [MS 488] Cory Library, Smith, Autobiography pp. 74, 76, 77, 102, Smith, Letter to Grey 15 Mar 1849 in Correspondence (1850).

29 Smith, Autobiography p. 90, Smith, Address to Caffer Chiefs 7 Jan 1836 in Autobiography. 


\section{To be a 'civilised' Roman}

Roman views on the nature of 'barbarism' and 'civilisation' are illuminating. In his speech against the exploitation of provincials by Verres, governor in Sicily, Cicero describes Verres as barbarous by association and in character. ${ }^{30}$ In his defence of Sulla, Cicero refers to Catiline and other Romans as being more barbarus than 'barbarous' nations. ${ }^{31}$ Here Cicero is attributing barbarous, uncivilised traits to Romans, as he does again when he comments on civilised conduct as a type of behaviour which he intimates Mark Antony lacks. ${ }^{32}$ As much as these were rhetorical means by which he could further discredit his opponents in judicial cases and speeches, by the use of what were obviously widely accepted understandings of civilisation and barbarism, ${ }^{33} \mathrm{I}$ would argue that Cicero viewed any individual as capable of being or behaving in a barbarous or civilised way, and he states more than once that barbarism and civilisation were based on manners and character rather than on language or nationality. ${ }^{34}$ Unlike the view of the ancient Greeks who defined a 'barbarian' as a non-Greek in speech, ethnicity or descent, the ancient Romans were more inclined to view civilisation in terms of culture and customs ${ }^{35}$ - that which could be 'learnt', rather than being innate. Veyne notes that humanitas was viewed by Romans as a merit, rather than a universal trait and that, like plants, humans were either wild or 'cultivated'. ${ }^{36}$

The essential capability of man to learn how to be civilised ${ }^{37}$ was affirmed by Roman writers in the explanation of their own history. Cicero writes of civilisation as being born in Greece and spreading to Rome, through all the earth to all other peoples ${ }^{38}$ - what he perceived to be 'the natural course of human history'.

30 Cic. Verr. 2.3.23, 2.4.112.

31 Cic. Sull. $75-76$.

32 Cic. Phil. 2.7-8.

33 Woolf 1998:60.

34 Cic. Rep. 1.58, Cic. Verr. 2.4.112.

35 Woolf argues that in conquering Greece and appropriating much of its culture in order to negotiate Roman identity as 'civilised', in the face of being 'barbarian' by Greek definition, the Romans redefined the concept to something that could be 'learnt' and 'adopted' (Woolf 1998:58-60 cf. Woolf 2011:112). It is possible that this definition also appealed to the English as their identity as 'civilised' was threatened by the description of Britons as 'barbarians' by the Romans unless they too viewed civilisation as something that 'progressive' societies adopted. By contrast, Veyne argues that the Romans needed to adopt Hellenistic traditions and the Greek language to prove that they knew the manners of the great international civilisation that Hellenism represented (Veyne 1993:356).

36 Veyne 1993:343.

37 Veyne comments that this could be related to the individual and society (Ibid., 343).

38 Cic. Flac. 62, Verr. 2.5.187, Sen. 1, Q. Fr. 1.1.27-9. As does Pliny in Ep. 8.24.2 
He writes of 'wolf-men' who lived together in packs before the time of civilisation or laws, who lived by strength and violence before those most wise among them perceived the 'teachableness of human nature' and brought themselves from a state of wildness and savagery, into one of justice, civilisation and urbanisation. ${ }^{39}$ Cicero ultimately acknowledged the Romans as having lived a barbarous life before being educated to a refined state of civilisation by the divine institutions of Athens. ${ }^{40}$ Civilisation was presented as a 'state of society' that applied to the whole of mankind. ${ }^{41}$

How 'civilisation' was imagined to be 'learnt' or adopted is another question. Valerius Maximus comments on the charm of humanitas as being able to 'find its way into the savage nature of barbarians softening the grim fierce eyes' of Rome's enemies. ${ }^{42}$ Roman writers often describe Germans, Gauls or Britons as being more or less barbarous or civilised than others depending on their proximity to and contact with Roman goods, customs and culture. ${ }^{43}$ Cicero alludes to the

39 Cic. Sest. 91. Vitruvius writes of the natural progression from barbarism to civilisation if in the proximity of civilised society, and the desire of men to do so (Vitr. 2.8.12) and describes at length how mankind equipped with ideas and purposes, constructed buildings and progressed by degrees to crafts and disciplines that led from a savage and rustic life to a state of civilisation (Vitr. 2.1.6-7).

40 Cic. Leg. 2.36, De Or. 1.33.

41 On the other hand both Cicero and Tacitus mention how the process can operate in reverse, and that people can be corrupted into being savage and wild (Cic. Rep. 2.27, Tac. Ann. 6.42), just as humanitas can be used to bring mankind out of that state (Cic. Rep. 2.27).

42 Val. Max. 5.1.6.

43 Caesar describes the Belgae as far removed from the humanitias of provincial Gaul (humanitate provinciae longissime absunt) and so unaffected by it (Caes. $B G$ 1.1.3), intimating that if they lived in closer proximity they could have changed and become more like those in provincial Gaul. Caesar comments on one tribe of Germans as being more civilised than another because their borders touched the Rhine and due to trade were more accustomed to Gallic fashions (Caes. BG 4.3.3-4). Caesar describes the inhabitants of Kent as humanissimi of all the Britons, as a maritime people and similar to the Gauls (Caes. $B G$ 5.14.1). Caesar also recounts how the Romans adopted barbarian ways of fighting because of their contact with and proximity to barbarians (Caes. $B G$ 1.44). Hirtius comments that the Treveri, by reason of their proximity to Germany, differed little from the Germans in cultu et feritate (Caes. $B G$ 8.25.2). Vitruvius advocates the natural progression of men from barbarism to civilisation if in the proximity of civilised society, and the desire of men to do so (Vitr. 2.8.12). Cicero also writes an interesting passage about a colony, far removed from the civilisation of Greece, and threatened by waves of barbarism from surrounding Gaul, and which in spite of this retained its civilised ways (Cic. Flac. 63), but there was evidently a danger of becoming barbarous - perceived of as living far removed from civilisation, in close proximity to barbarous peoples. Suetonius and Strabo also write of 'degrees' of barbarity. Suetonius comments on some Gauls as semibarbari (Suet. Jul. 76.3). Strabo 
geographical 'spread' of civilisation' ${ }^{44}$ Strabo writes of the Gauls as turning to civilised life, farming, and Roman lifestyles due to the dominance of the Romans. ${ }^{45}$ But this 'spread' of civilisation was viewed as much more than a circumstantial outcome of expansion.

It is evident that some Romans, at least, subscribed to an imperial vocation ${ }^{46}$ and seem to have seen themselves playing a role in the civilising of the 'other' ${ }^{47}$ In a letter to his brother Quintus, Cicero outlines the duty of the Romans to bestow upon other nations that which was given to the Romans themselves by the Greeks, civilisation, and that it was incumbent upon a man to study the 'other', consider their welfare and security, and to teach them the lessons of arts and studies. ${ }^{48}$ Pliny the Elder describes Rome as the nursling and mother of all other lands, chosen by the gods to unite scattered peoples, bring them together with language and to give to mankind humanitas. ${ }^{49}$

Granted, we are only able to study a small fragment of surviving Latin literature, but it was this same literature that was available to men like Sir Harry Smith to read and reflect on.

\section{Smith's civilising mission}

For the most part, Smith, like the Romans, believed that 'civilisation' was something that could be 'learnt'. ${ }^{50}$ He viewed humanity as balanced between 'savagery' and the 'educated Christian'. ${ }^{51}$ He remarks on 'barbarism' as a 'state of

comments on the habits of the Britons as more barbarous than others (Strab. 4.5.2). This concept is also discussed in Schadee 2008:167-168, Rawlings 1998:172, Balsdon 1979:65. Riggsby makes an interesting point of how Caesar portrays Gaul as a place of 'bad civilisation' but further Germany as a place of 'no civilisation' (Riggsby 2006:122).

44 Cic. Flac. 62, Verr. 2.5.187, Sen. 1, Q. Fr. 1.1.27-9. As does Pliny in Ep. 8.24.2.

$45 \quad$ Strab. 4.1.2, 4.1.5, 4.1.11, 4.1.12.

46 This is reflected in Verg. Aen. 6.851-3 (tu regere imperio populos, Romane, memento (hae tibi erunt artes), pacique imponere morem, parcere subiectis et debellare superbos). Woolf also sees this 'sense of duty' as echoed in Virgil's Jupiter when he speaks of Rome's skill to rule over peoples and to impose morality (Woolf 1998:57). See also Tac. Agr. 13.3.

47 Woolf 1998:48-50.

48 Cic. Q. Fr. 1.1.27.

49 Plin. HN 3.39-40. Woolf sees this echoed in the image of the transformative power of Rome found in accounts of Gaul by Caesar and Strabo, in which Rome is presented as providing conditions for others to become civilised, such as the provision of education (Woolf 1998:57).

so Smith, Autobiography p. 95.

51 Smith, Letter to D'Urban 23 Nov 1835 in Letterbook. 
human nature, ${ }^{52}$ and, similarly to Cicero's description of the Romans, describes the English as once naked, ignorant and cruel before they discovered Christianity and advanced towards civilisation. ${ }^{53}$ Smith remarks on uncivilised conduct as a 'habit', one that was thrown off by the English a long time ago, ${ }^{54}$ although he describes the pillage and rape by the British military in Badajoz" as 'civilized man let loose of morals, a far greater beast than the savage, more refined in cruelty' ${ }^{56}$ - as if although they still had the capacity to act barbarously they did so in a more 'refined' way.

Despite initial outbursts that the Xhosa people were 'irreclaimable' from barbarism, ${ }^{57}$ Smith soon began to write of the possibility of the Xhosa people progressing and striding toward civilisation. ${ }^{58}$ What brought about this change was a radical modification in policy initiated by Sir Benjamin D’Urban, his superior, who, instead of driving the Xhosa over the Kei River, which proved an impossible task, ${ }^{59}$ decided to follow the advice first given to him by Dr John Philip, an influential missionary at the Cape and supporter of the humanitarian movement in London. ${ }^{60}$ Philip had advised D'Urban that he would not object to the annexation of more land from the Xhosa, provided that he civilise them on their land, 'on the plan adopted by the ancient Romans' ${ }^{61}{ }^{61}$ Following the lead of D'Urban, who hoped to 'civilise' the Xhosa 'by the power of legal coercion ... humane persuasion and

52 Smith, Autobiography p. 102, Smith, Letter to D'Urban 17 April 1836 in Letterbook.

53 Smith, Address to Caffer Chiefs 7 Jan 1836 in Autobiography.

54 Smith, Address to Caffer Chiefs 7 Jan 1836 in Autobiography. Smith also refers to civilised 'habits' in Smith, Letter to D'Urban 6 Oct 1835 in Letterbook.

55 This incident refers to the actions of the British following the siege and capture of Badajoz in Spain in 1812 (Smith, Autobiography vol.1 pp. 61-68).

56 Mostert 1992:662.

57 Smith, Letters to D’Urban 21 July 1835, 16 Aug 1835 in Letterbook. According to Mostert, the word 'irreclaimable' was used several times by D'Urban and Smith to describe Xhosa in order to justify the treatment of them by the British, from Hintza's death to the annexation of more land, and the phrase enraged the humanitarian party and missionary movements in London and the Cape for its implications on the futility of missionary endeavours. (Mostert 1992:727, 736, Crais 2001:119). Lester argues that the discourse of the Xhosa as too savage to be reclaimed was common among the frontier settlers and many administrators, Smith and D'Urban particularly (Lester 1998b:8-10).

58 Smith, Letters to D'Urban 4 Aug, 1 Sept, 22 Sept, 6 Oct, 12 Oct, 17 Nov, 28 Nov, 8 Dec, 15 Dec 1835 in Letterbook.

59 Peires 1982:112, Mostert 1992:735, Lester 1998a:227.

60 Walker 1957:191. For more information on the humanitarian movement in London see Galbraith 1963:4-5, 73-76, and on the philanthropic influence at the Cape see van Aswegen 1993:217, Mostert 1992:736, Lester 1998b:4-6, Strobel 2008:73.

${ }^{61}$ Report of Aborigines Committee 1836, quoted in Walker 1957:190. 
example' ${ }^{62}$ Smith soon took on the task wholeheartedly and, as Lester puts it, 'as if intended all along, a discourse of their experimental 'civilisation' was developed' ${ }^{63}$

Taking D'Urban's policy further, Smith envisaged a 'new era ... opening to the world in respect to civilisation' ${ }^{64}$ Smith hoped that Christianity and civilisation would in time be established from Queen Adelaide province to Natal, ${ }^{65}$ as neighbouring nations would by imitation and example adopt civilisation. ${ }^{66}$ In these broad visions we see Smith adhering to the idea that civilisation spreads by proximity, whereas when he wrote more specifically about his plans he very forcefully emphasised his intention to actively civilise the Xhosa ${ }^{67}$ rather than the circumstantial implications of the 'spread' of 'civilisation'. Smith believed the Xhosa capable of advancing in civilisation only if they followed his rules ${ }^{68}$ and, according to Mostert, he viewed it his duty and divine calling to bring about that change. ${ }^{69}$

Many of the methods Smith claimed to intend to use to bring about the civilisation of the 'other' have some striking similarities to the images we have of Roman precedent. Smith writes of promoting the pleasures and desire of wealth brought about by civilisation and commerce, ${ }^{70}$ of leading by quiet and impressive persuasion, urging and inspiring the Xhosa by example and right conduct, by instilling respect, restraint, industry, religion and an admiration of Englishmen. ${ }^{71}$ He believed it imperative that British leaders act with decision, judgement and equity $^{72}$ and that good conduct, character and manners be impressed upon the 'other' by example in this new system. ${ }^{73} \mathrm{He}$ spent hours a day, he claims, with chiefs on the subjects of trade and improvement, ${ }^{74}$ and writes of holding great meetings where he expounded the principles of honesty and religion, ${ }^{75}$ convinced

\footnotetext{
62 Walker 1957:186.

63 Lester 1998a:228.

${ }^{64}$ Smith, Letters to D'Urban 1 Nov, 30 Nov 1835 in Letterbook.

65 Smith, Letter to D'Urban 8 Dec 1835 in Letterbook.

${ }_{66}$ Smith, Letters to D'Urban 8 Dec, 15 Dec 1835 in Letterbook.

${ }_{67}$ Smith, Letter to D'Urban 17 Nov, 22 Nov, 25 Nov 1835 in Letterbook.

68 Smith, Address to Caffer Chiefs 7 Jan 1836 in Autobiography.

69 Mostert 1992:763, 950. This can be compared to the role the idea of divine will played in the Roman conception of an imperial vocation (Woolf 1998:48).

70 Smith, Letter to D'Urban 15 Dec 1835 in Letterbook.

71 Smith, Letters to D'Urban 6 Oct 1835, 1, 17, 23, 25 Nov 1835 in Letterbook.

72 Smith, Letter to D'Urban 30 Nov 1835 in Letterbook.

73 Smith, Letter to D'Urban 19 Dec 1835 in Letterbook.

74 Smith, Letter to D'Urban 12 Oct 1835 in Letterbook.

75 Smith, Letter to D'Urban 17 Nov 1835 in Letterbook.
} 
he was exciting and inspiring them with the power and regularity of all that was English by shows of pomp and ceremony. ${ }^{76}$

\section{Beyond the model of Agricola}

The overall tone of Smith's discourse and self-image recalls the description of Tacitus' Agricola in Britain praising 'progress', rebuking those who did not adopt Roman ways, and spurring on rivalry for his esteem. ${ }^{77}$ Tacitus goes on to describe Agricola in Britain as giving encouragement to individuals and assistance to communities in the construction of temples, markets and private houses ... having the sons of the chieftains educated in the liberal arts. ${ }^{78}$ Scholars argue that a provincial governor's role would have been to promote, guide and perhaps provide models for 'civilising projects'. ${ }^{79}$ The interaction between the local elite and the Roman governors' entourage was seen as important in influencing local cultural change. ${ }^{80}$ Although the provinces were to a large extent administered by the provincial aristocracy, ${ }^{81}$ it was to this local elite, whom Rome bolstered up as local magistrates ${ }^{82}$ that most encouragement was given to become like the Romans, encouraged by ideology that was promoted by a provincial governor and his entourage. ${ }^{83}$ Roman conceptions of civilisation offered a belief system that was supposed to have convinced an educated elite to be of a shared identity and mission $^{84}$ which then would ultimately influence larger groups of native peoples ${ }^{85}$

The image of a leader inspiring by 'example' and encouraging emulation for 'civilised' life, was evidently something that Smith saw himself doing among the Xhosa. However, Smith's efforts to 'civilise' went far further than attempting to inspire and encourage. He sought to introduce British $\operatorname{law}^{86}$ and a new magistracy system whereby chiefs were appointed as native magistrates and field

76 Smith, Letter to D'Urban 10 Jan 1836 in Letterbook.

77 Tac. Agr. 21.1. See Smith, Letters to D'Urban 17, 25 Nov 1835, 28 Jan, 12 Feb, 25 Mar, 16 June 1836 in Letterbook, Smith, Letter to Grey 15 Mar 1849 in Correspondence (1850). Although in his writings about the Eastern Cape Smith does not refer to Tacitus' Agricola, he is likely to known its contents, especially as it had been used from the $16^{\text {th }}$ century (sometimes with great liberties taken) for histories about the British Isles: see Bradley 2011:134.

Tac. Agr. 21.1-2.

Woolf 1998:68-69, 71, Laurence 2001:3

Laurence 2001:4.

Goodman 1997:107.

Ibid., 138.

Ibid., 207-8.

Woolf 1998:74-5.

Millett 1990:2.

Smith, Letters to D'Urban 1, 17 Nov, 8 Dec 1835 in Letterbook. 
commandants. ${ }^{87}$ According to Walker, D'Urban hoped to substitute colonial law for tribal custom. ${ }^{88}$ Smith sought to oblige the chiefs and councillors to wear European clothing $^{89}$ and tried to encourage European methods of agriculture and horticulture by introducing schools of industry, teaching the use of implements and making presents to the chiefs of ploughs, harrows and implements of husbandry. ${ }^{90}$ Smith wrote to his wife about how he hoped to see the Xhosa taught how to build cottages and how nothing would tend to their civilisation more than cottage living. ${ }^{91}$ He later described how his wife would spend hours with the Xhosa chiefs' wives teaching them needlework and Christian morals. ${ }^{92} \mathrm{He}$ actively sought to control trade and introduce the use and circulation of money, going so far as to prohibit barter. ${ }^{93}$

After his recall in April of 1836, consequently blaming the Imperial government for frustrating his efforts, ${ }^{94}$ Smith later returned in 1847 as Governor of the Cape and attempted to renew his previous system. ${ }^{95}$ He divided Xhosa land into 'counties' with English names, he sought to teach them to plough and to trade and once again envisaged establishing schools where the Xhosa were to learn to speak English. ${ }^{96} \mathrm{He}$ seems to have believed more than ever in the 'civilisation' of the Xhosa, ${ }^{97}$ a conviction that was to falter in the conflict to come, when he learnt of his 'subjects" rejection of his system..$^{98}$ Although he still wrote of the possible 'civilisation' of the 'other', Smith seems to have given up on his methods and

87 Smith, Letters to D'Urban 17 Nov,19 Dec 1835,10 Jan 1836 in Letterbook.

88 Walker 1957:193.

89 Smith, Letters to D'Urban 1, 22, 27 Sept, 30 Nov 1835, 10 Jan 1836 in Letterbook. Lester argues that the adoption of European clothing was held as one of the most important indicators of transformation as it was the most visible and politically potent (Lester 1998a:229-230).

90 Smith, Letters to D'Urban 5, 6, 26 Oct 1835 in Letterbook. According to Lester, the use of ploughs in agriculture was part of a wider vision of the transformation of gender roles, where men were expected to work in the fields, not women (Lester 1998a:229).

91 Smith, Letter to Juana 19 April 1835 in Autobiography. Crais notes the association of huts with 'savagry' (sic) (Crais 2001:138).

92 Smith, Autobiography pp. 90-91.

93 Smith, Letters to D'Urban 6 Oct 1835, 17 Dec 1835 in Letterbook. See also Mostert 1992:766.

94 Smith, H, Letter to D'Urban 20 Oct 1836 [MS 482] Cory Library, Smith, Autobiography pp. 90, 95.

95 Smith, Letter to Mackinnon 5 Mar 1849, Letters to Grey 15 Mar 1849, 7 Jan 1850, Speech to Xhosa chief 7 Jan 1848 in Correspondence (1850). See also Peires 1982:165, Mostert 1992:933.

96 Peires 1982:166-7, Mostert 1992:939.

97 Harington 1980:170.

98 Ibid., 188, 197. 
efforts to inspire and coerce, and foresaw only being able to forcibly 'civilise' a downtrodden and subjected people - as the Xhosa evidently did not wish to put aside their own culture to adopt foreign ways. In a letter to Grey he stated that the value of civilisation could only be felt by the people eventually after the imposition of strict control and border systems, tight laws and military control. ${ }^{99}$

Some of Smith's efforts at direct intervention in the realm of politics, law and economics would seem to bear some similarity to Roman precedent in the western provinces. We are told by Tacitus that councils, magistrates and constitutions were imposed upon the society of the 'other'. ${ }^{100}$ Woolf states that Roman generals everywhere were regularly described as setting up and correcting political institutions and laws. ${ }^{101}$ Goodman comments on Roman currency being circulated through officials and soldiers and required by taxation. ${ }^{102}$ It has been argued that by instituting Roman-style political institutions, laws, currency and a magistracy amenable to the process, the Romans attempted to 'civilise' the 'other', overtly encouraging urbanisation, ${ }^{103}$ and the adoption and emulation of Roman education, values and behaviour. ${ }^{104}$

\section{Conclusion}

However, although acculturation seems evident in Roman times, ${ }^{105}$ it is debated just how far the Roman government went to in order to induce the 'other' to become civilised. ${ }^{106}$ And despite Smith's various aims and methods by which he attempted to civilise the 'other', these were never completely carried out, not particularly

99 Smith, Letter to Grey 16 Jan 1852 in Correspondence (1853).

100 Tac. Ann. 11.19.

101 Woolf 1998:71.

102 Goodman 1997:142-46.

103 Ibid., 137.

104 Woolf 1998:71-2.

105 See for example in Millett 1990 and Woolf 1998. For discussion on the debate around the ideas of 'Romanisation', 'acculturation', or 'cultural change' specifically see Millett 1990:1-2, Jones 1991:115, Hingley 1996:39-45, Woolf 1997, Levick 2000:162. For a similar argument for the negotiation of British identity and culture in the Cape Colony, see Bickford-Smith 2003.

106 There is general agreement among scholars that there is little evidence for substantial imperial investment of funds in the any civilising process (Woolf 1998:68-69, 71, Laurence 2001:3). For different arguments on whether or not it was Roman policy to actively civilise the 'other' see Woolf 1998:60-67, Haverfield 1915:14, 16, Hingley 1996:41.) Veyne argues that the Roman government never sought to civilise the 'other' but that the provincials spontaneously civilised themselves (Veyne 1993:365). 
successful nor supported by the resources of the British government in his time. ${ }^{107}$ But the reality and success of their relative efforts and whether or not the 'other' actually did adopt various cultural practices imposed upon them are less relevant here, ${ }^{108}$ than the fact that the discourse and visions ascribed to by both Romans and Smith were remarkably similar.

One must, nevertheless, note an important distinguishing difference between Roman and Smith's idea of 'civilising', namely Smith's connection of civilisation with Christianity. ${ }^{109}$ Smith often emphasised Christianity and the missionaries as connected to his 'civilising mission' ${ }^{110} \mathrm{He}$ saw clergymen, magistrates, religious institutions, schools of industry and the military, all playing vital roles in the successful fulfilment of his goal. ${ }^{11}$ At the Cape and elsewhere in the British Empire, Christian missionaries as well as many colonial administrators

107 Mantena 2011:58 conveys a slightly different picture of British India, with greater emphasis on acculturation. During Smith's time civilising efforts remained largely 'ideas' as very limited financial assistance for such programmes was provided by the British government (Strobel 2008:85). Smith's efforts, for what they were worth, largely failed. Peires argues that had the system been maintained for much longer after the dissolution of the province of Queen Adelaide, the chiefs would have staged an uprising against the Colony (Peires 1982:114-115). The supposedly 'ingratiating' and 'humble' chiefs (Smith, Letters to D'Urban 27, 28 Sept 1835, 5, 6, 12 Oct 1835 in Letterbook, Smith, Address to Caffer Chiefs 7 Jan 1836 in Autobiography) had been playing Smith far more successfully than he imagined he was playing them (Mostert 1992:772, 938, 1108). In flattering Smith, they managed to convince him to give them more land than the government had originally intended (Peires 1982:114). After a number of letters to D'Urban describing the chiefs as acting amenable to and grateful for his policy (Smith, Letters to D'Urban Sept 1835 in Letterbook), Smith recounts how 'Maqoma prayed so hardly for a small piece of land ... that Captain Stretch and myself decided on giving it to him' (Smith, Letter to D'Urban 27 Sept 1835 in Letterbook.) In 1852, faced with another fierce resistance campaign against British rule and the desertion of his most 'loyal' Xhosa police (Mostert 1992:1040-1112), Smith acknowledged that his efforts had failed and that the Xhosa people should live according to their own laws and customs (Mostert 1992:1073-4). Regarding the Xhosa tribes under British protection, he wrote: 'let them alone, we have seized British Kaffraria for no other purpose than to provide a frontier for the Colony' (Smith, Letter to Godlonton 10 Jan 1852 in Godlonton Corresp.).

108 For the Xhosa see van Aswegen (1993:201-211), Mostert (1992:988) and Lester (1998a:240-241). For the Roman 'other' see Goodman (1997:214-215).

109 According to Mostert civilisation depended upon the adoption of Christianity by the Xhosa, which led to Smith's dependence on missionaries for education and conversion (Mostert 1992:766-7). Although he initially held missionaries in very low regard, he was by 1848 sending them a circular requesting their opinions on the best methods of civilising and Christianising the Xhosa (Mostert 1992:949). Smith, Letters to D'Urban 4 Aug, 6 Oct, 15 Dec 1835 in Letterbook.

111 Smith, Letter to D'Urban 27 Sept, 17 Nov 1835 in Letterbook. 
sought to both convert and 'civilise' the 'other' and saw these two as interrelated processes, ${ }^{112}$ whereas, in any Roman endeavour during the period being studied there was never any imposition of religious morality, and the Romans were indifferent to the 'eternal salvation' of their subjects, ${ }^{113}$ unlike the European missionaries. Even so, both Romans and Smith did at times forbid and outlaw religious practices ${ }^{114}$ particularly when they were seen as a political threat to imperial rule. ${ }^{115}$ Another unique aspect of Smith's vision of civilising the 'other' was the emphasis on 'industry' and the work ethic as an aspect of civilisation, which is possibly connected with the role of 'labour' which the British saw the 'other' as fulfilling within their economic system. ${ }^{116}$

112 For further information on Christian missionary activities in the Eastern Cape see Wilson 1969:238, 264-268, Galbraith 1963:79-97, Davenport 1991:160-163, Crais 2001:100-101, Lester 1998a:238-241. Governors such as Shepstone and Grey were later to advocate and implement the idea of civilising the 'other' even more strongly than Sir Harry Smith. For Grey's policies see Wilson 1969:260-264, Peires 1989:45-73, Davenport 1991:121-122, Thompson 1990:77. For Shepstone's policies see McClendon 2004:339 -358, Thompson 1990:98.

113 Veyne 1993:367. Unlike Christianity, Roman religion was pluralistic and polytheistic in nature, and Gruen argues that far more than 'tolerating' other religions, Rome ostensibly embraced alien cults (Gruen 2006:467).

114 The Romans did at various times go as far as banning Druidic religious practices (Goodman 1997:208, Isaac 2004:422-3, Gruen 2006:472, Balsdon 1979:65). So too Smith attempted to discredit and ban certain Xhosa customs and practices (Smith, Letters to D'Urban 6 Oct, 8, 28 Dec 1835, 4, 14, 28 Feb, 6 June 1836 in Letterbook, Smith, H, Letter to D'Urban 20 Oct 1836 [MS 482] Cory Library. See also Wilson 1969:266, 269-270, Mostert 1992:766, 768, 937, 962, 998-999, Lehmannn 1977:190191, Strobel 2008:78).

115 Scholars argue that the reason possibly had more to do with the Druids as being seen as a dangerous, subversive force that held significant authority within the Celtic population (Syme 1970:25, Isaac 2004:422-3, Gruen 2006:472). Smith viewed what he termed 'witchcraft' as the means by which the chiefs exerted authority and accumulated wealth (Smith, H., Letter to D'Urban 20 Oct 1836 [MS 482] Cory Library, Smith, Autobiography pp. 74-76, also as discussed by Strobel 2008:78). As his primary objective was to undermine the power of the chiefs (Mostert 1992:762, Lester 1998a:236), this custom was seen as a direct threat to his plans.

116 Smith viewed the ploughing, cultivating and habits of industry as the first step to civilisation (Mostert 1992:945). The link between Christian conversion, the 'gospel of work' and industry; and the adoption of 'civilised' European ways of life, is evident from the early missionary endeavours in the Eastern Cape (Wilson 1969:239, 265-267, Davenport 1991:160-163, Mostert 1992:947; Crais 2001:102-103). The more dubious connection of between 'civilising' endeavours with ideas of industry and work ethic come to light at a later stage when Smith's government sought to alleviate the labour shortage in the Colony by a scheme of indenturing Xhosa, particularly children, as labour (Peires 1982:167-8). Van Aswegen notes that under Smith's governorship the Xhosa were taught the 'value of labour' as he endeavoured to integrate the Xhosa into 
Yet, in the face of such obvious differences, it still fascinates me that such similar views and ideas were used by people thousands of years apart. What purpose could such a discourse serve? For a conquering people, whether Imperial Rome or the British Empire, the image of an inferior or uncivilised 'other' in opposition to their own supposedly 'elevated state of society' provided justification for warfare against and domination of other peoples, ${ }^{117}$ as they viewed themselves destined to rule as 'superior' beings. ${ }^{118}$ It also provided justification for coercing the 'other' to adopt the ways of the conqueror as they were supposedly 'rescuing' the 'other' from an undesirable state. As control and rule was the objective, ${ }^{119}$ this could also possibly have seemed easier if the 'other' subscribed to their laws and ways of life. Particularly in the case of Smith and D'Urban, descriptions and visions of 'civilising' the 'other' were only entertained when they attempted to bring the 'other' under direct rule during the process of expanding and annexing the area between the Fish and Kei rivers. ${ }^{120}$ After Smith was first recalled from the Cape, D'Urban's system disbanded and the province and its land given back to the Xhosa in 1836, there was no further move towards 'civilising' the 'other' by the British government until Smith returned to once again annex land from the Xhosa.

\section{BIBLIOGRAPHY}

Anon., 1850. Correspondence with the governor of the Cape of Good Hope relative to the state of the kafir tribes on the eastern frontier of the colony, Cape of Good Hope, presented to both houses of parliament by command of Her Majesty 14 Aug 1850. London: William Clowes \& Sons. Cory Library.

Anon., 1853. Correspondence: Government of the Cape of Good Hope relative to the state of the kafir tribes and the recent outbreak on the eastern frontier of the colony, Cape of Good Hope, presented to both houses of parliament by command of Her Majesty May 31 1853. London: Georbe Edward Eyre \& William Spottiswoode. Cory Library.

Arndt, J C 2010. Treacherous savages and merciless barbarians: Knowledge, discourse and violence during the Cape frontier wars, $1834-1853$. The Journal of Military History 74:709-735.

the white capitalistic system (van Aswegen 1993:218), largely as a labour supply. Cf. Mostert 1992:948.

117 Jahoda 1999:11, 16, 148, 217, Woolf 1998:56-7, Lester 1998b:10-12, Mostert 1992:738, Arndt 2010:710-11, 734-5, Webster 1996:117.

118 Woolf 1998:48, Miller \& Savage 1977:120, Harington 1980:171.

119 Smith's primary objective was to curb the power of the chiefs (Wilson 1969:243-244, Peires 1982:113).

120 Mostert 1992:933. 
Ayto, J 2002. Oxford school dictionary of word origins. Oxford: Oxford University Press.

Balsdon, J P V D 1979. Romans and aliens. London: Gerald Duckworth \& Co.

Bickford-Smith, V 2003. Revisiting anglicisation in the nineteenth-century Cape Colony. The Journal of Imperial and Commonwealth History 31.2:82-95.

Bradley, M 2011. Tacitus' Agricola and the conquest of Britain. In Bradley, M (ed). Classics and imperialism in the British empire, 123-157. Oxford Scholarship Online.

Crais, C C 2001. The making of the colonial order: White supremacy and black resistance in the Eastern Cape, 1770-1865. Johannesburg: Witwaterstrand University Press.

Davenport, T R H 1991. South Africa: A modern history: Fourth edition. London: Macmillan.

Galbraith, J S 1963. Reluctant empire: British policy on the South African frontier 1834 -1854. Berkeley: University of California Press.

Goodman, M 1997. The Roman world: 44BC-AD 180. New York: Routeledge.

Gruen, E S 2006. Romans and others. In Rosenstein, N \& Morstein-Marx, R (eds.), A companion to the Roman republic, 459-477. Chichester: WileyBlackwell.

2010. Rethinking the Other in antiquity. Princeton: Princeton University Press.

Harington, A L 1980. Sir Harry Smith: Bungling hero. Cape Town: Tafelberg Publishers.

Haverfield, F 1915. The Romanization of Roman Britain. Oxford: Clarendon Press.

Hingley, R 1996. The 'legacy' of Rome: The rise, decline, and fall of the theory of Romanization. In Webster \& Cooper 1996:34-48.

Hirsch, S W 1985. The friendship of the barbarians: Xenophon and the Persian Empire. Hanover, N.H.: University Press of New England.

Isaac, B 2004. The invention of racism in classical antiquity. Princeton: Princeton University Press.

Jahoda, G 1999. Images of savages: Ancients roots of modern prejudice in western culture. London: Routledge.

Jones, R F J 1991. Cultural change in Roman Britain. In Jones, R F J (ed), Britain in the Roman period: Recent trends, 115-120. Sheffield: J R Collis.

King, R 1999. Orientalism and religion: Post-colonial theory, India and the mythic East'. London: Routledge.

Laurence, R 2001. Introduction. In Laurence, R \& Berry, J (eds), Cultural identity in the Roman Empire, 1-9. London: Routledge.

Lehmann, J H 1977. Remember you are an Englishman: A biography of Sir Harry Smith 1787-1860. London: Jonathan Cape. 
Lester, A 1998a. Settlers, the state and colonial power: The colonization of Queen Adelaide Province, 1834-37. The Journal of African History 39. 2:221-245.

— 1998b. 'Otherness' and the frontiers of empire: the Eastern Cape Colony, 1806-1850. Journal of Historical Geography 24.1:2-19.

Levick, B 2000. The government of the Roman Empire: A sourcebook. London: Routledge.

Macfie, A L 2002. Orientalism. London: Routledge.

Mantena, R S 2010. Imperial ideology and the uses of Rome in discourses on Britain's Indian empire. In Bradley, M (ed.), Classics and imperialism in the British empire, 54-74. Oxford Scholarship Online.

McClendon, T 2004. The man who would be Inkosi: Civilising missions in Shepstone's early career. Journal of Southern African Studies 30.2:339-358.

Miller, D H \& Savage, W W Jr 1977. Ethnic stereotypes and the frontier: A comparative study of Roman and American experience. In Miller, D H \& Steffen, J O (eds), The frontier: Comparative studies, 109-137. Oklahoma: University of Oklahoma Press.

Millett, M 1990. The romanization of Britain: An essay in archaeological interpretation. Cambridge: Cambridge University Press.

Moore Smith, G C (ed.) 1901. The autobiography of lieutenant-general Sir Harry Smith. London: John Murray.

Mostert, N 1992. Frontiers: The epic of South Africa's creation and the tragedy of the Xhosa people. London: Pimlico.

Peires, J B 1982. The house of Phalo. Johannesburg: Ravan Press.

Rawlings, L 1998. Caesar's portrayal of Gauls as warriors. In Welch, K \& Powell, A (eds), Julius Caesar as artful reporter: The war commentaries as political instruments, 171-192. London: Duckworth.

Riggsby, A M 2006. Caesar in Gaul and Rome: War in words. Austin: University of Texas Press.

Said, E W 1978. Orientalism: Western conceptions of the Orient.New York: Penguin Group.

Schadee, H 2008. Caesar's construction of Northern Europe: Inquiry, contact and corruption in 'De Bello Gallico'. The Classical Quarterly. New Series. 58.1:158-180.

Smith, Sir H. The Godlonton correspondence: Letters to the Hon R Godlonton, 10.2.1837 19.1.1859 [A 47] The Western Cape Archives and Records Services.

Smith, Col H G W. Letterbook, Eastern frontier, 1835-1836 [GH 34/7 - 8] The Western Cape Archives and Records Service.

Smith, H. Letter to D'Urban 20 Oct 1836 [MS 482] Cory Library.

Smith, H. Letter to Sir G. Napier 28 Jan 1838 [MS 488] Cory Library. 
Smith, H. Letter to Lord Glenelg 15 Dec 1837 [MS 501] Cory Library.

Stray, C 1998. Classics transformed: Schools, universities, and society in England, 1830-1960.Oxford: Clarendon Press.

— 2001. Curriculum and style in the collegiate university: Classics in nineteenth century Oxbridge. In Feingold, M (ed), History of universities Vol XVI2, Vol 16, 183-218. Oxford: Oxford University Press.

Strobel, C 2008. The testing grounds of modern empire: The making of colonial racial order in the American Ohio country and the South African Eastern Cape, 1770s-1850s. New York: Peter Lang Publishing.

Syme, Sir R 1970. Ten studies in Tacitus. Oxford: Clarendon Press.

Thompson, L 1990. A history of South Africa. Sandton: Radix.

van Aswegen, H J 1993. History of South Africa to 1854. Pretoria: Academica.

Varisco, D M 2007. Reading orientalism: Said and the unsaid. Seattle: University of Washington Press.

Veyne, P 1993. Humanitas: Romans and non-Romans. In Giardina, A (ed), The Romans, 342-369. Chicago: University of Chicago Press.

Walker, E A 1957. A history of Southern Africa. London: Longmans, Green and Co.

Webster, J 1996. Ethnographic barbarity: Colonial discourse and 'Celtic warrior societies'. In Webster \& Cooper 1996:111-123.

Webster, J \& Cooper, N (eds) 1996. Roman imperialism: Post-colonial perspectives. Leicester: University of Leicester.

Wilkinson, L P 1982. Cicero and the relationship of oratory to literature. In Kenney, E J \& Clausen, W V (eds), The Cambridge history of classical literature: II Latin literature, 230-267. Cambridge: Cambridge University Press.

Wilson, M 1969. Co-operation and conflict: The Eastern Cape frontier. In Wilson, M \& Thompson, L (eds), The Oxford history of South Africa, 233-271. Oxford: Clarendon Press.

Woolf, G 1997. Beyond Romans and natives. World Archaeology 28.3:339-350.

- 1998. Becoming Roman: The origins of provincial civilisation in Gaul. Cambridge: Cambridge University Press.

2011. Tales of the barbarians: Ethnography and empire in the Roman west. Chichester: Wiley-Blackwell. 